\title{
Serum Clusterin In Patients With Chronic HCV infection Related Cirrhosis
}

\section{Elham O. Hamed, Tamer M. Abdel-Latef, Ahmed S. Mahmoud, Katren Y. Fahem.}

Department of clinical and chemical pathology, Sohag Faculty of Medicine, Sohag University.

\section{Abstract:}

Cirrhosis is a condition in which the liver does not function properly due to long term damage. Typically, the disease comes on slowly over months or years. Cirrhosis is characterized by the replacement of normal liver tissue by scar tissue.

Clusterin (apolipoprotein $\mathrm{J}$ ) is a 75 - $80 \mathrm{kDa}$ disulfide-linked heterodimeric protein associated with the clearance of cellular debris and apoptosis.

Objective: We aimed to evaluate the diagnostic performance of serum CLU level in diagnosing chronic $\mathrm{HCV}$ infection-related cirrhosis, and comparing it to that of alpha fetoprotein (AFP).

Methods: Case control study was carried out in the Clinical Pathology Department, Faculty of medicine, Sohag university hospital.Twenty cases of apparently healthy subjects and 20 cases of chronic HCV infection-related cirrhosis (CHC cases) were included in this study. Serum CLU concentration was determined using a quantitative sandwich enzyme immunoassay technique.

Results: Serum clusterin level showed a significant decrease in the CHC group compared to the control group $(88.3 \pm 30.7$ vs. $110.7 \pm 30.1)$.

Conclusion: CLU is decreased in the serum of patients with established CHC.

\section{Introduction}

Cirrhosis is a condition in which the liver does not function properly due to longterm damage. This damage is characterized by the replacement of normal liver tissue by scar tissue. Typically, the disease develops slowly over months or years. Early on, there are often no symptoms. As the disease worsens, a person may become tired, weak, itchy, have swelling in the lower legs, develop yellow skin, bruise easily, have fluid build up in the abdomen, or develop spider-like blood vessels on the skin. The fluid build-up in the abdomen may become spontaneously infected. Other complications include hepatic encephalopathy, bleeding from dilated veins in the esophagus or dilated stomach veins, and liver cancer. Hepatic encephalopathy results in confusion and may lead to unconsciousness (National Institute of Diabetes and Digestive and Kidney Diseases.,2015).

Cirrhosis is most commonly caused by alcohol, hepatitis $\mathrm{B}$, hepatitis $\mathrm{C}$, and non-alcoholic fatty liver disease (Abubakar et al.,2015).

Ideally, for timely treatment, the biomarker(s) that could recognize the fibrosis in the early stages of hepatic disorder to prevent the progression of cirrhosis to $\mathrm{HCC}$ is required (Gangadharan et al.,2007).

CLU is a molecular chaperone responsible for aiding protein folding of secreted proteins, and its three isoforms have been differentially implicated in pro- or antiapoptotic processes. Through this function, CLU is involved in many diseases related to oxidative stress, including neurodegenerative diseases, cancers, inflammatory diseases, and aging (Koltai, 2014 ,Lin et al., 2014 and Sansanwal et al., 2015 ). CLU gene is 
highly conserved in species, and the protein is widely distributed in many tissues and organs, where it participates in a number of biological processes, including lipid transport, membrane recycling, cell adhesion, programmed cell death, and complement-mediated cell lysis (Koltai, 2014 ,Lin et al., 2014 and Sansanwal et al., 2015 ). CLU activity is also involved in infectious diseases, such as hepatitis $\mathrm{C}$. CLU is induced by the stress of hepatitis $\mathrm{C}$ viral infection, which disrupts glucose regulation. The chaperone protein then aids hepatitis $\mathrm{C}$ viral assembly by stabilizing its core and NS5A units (Lin et al.,2014).

Objectives:

The aim of the present study was to determine serum CLU concentration in $\mathrm{CHC}$, as well as assess the use of CLU measurement vs. AFP in the $\mathrm{CHC}$ patients.

Patients and methods:

Individuals in this study are classified into two groups based on clinical and laboratory characteristics:

- Group (1) which includes patients with chronic HCV infection-related cirrhosis (20) patients (CHC Group).

- Group (2) or control group which includes (20) apparently healthy age and sex-matched subjects with no history of previous liver disease.

All subjects (patients and controls) will be subjected to:

1- Complete history taking to retrieve information about health status, current medications, alcohol consumption, and history of viral or toxic hepatitis and general examination.

2- The following parameters are done in this study:

a. Routine investigations:

- Complete blood count.

- Prothrombin time and concentration.

- Liver function tests.

- Renal function tests.

- Random blood sugar.

- Serological testing for anti-HCV and hepatitis B virus surface antigen, antiHIV and anti-bilharzial antibodies.

b. Specific investigations:

- AFP assays

- Serum Clusterin

\section{Results of the study}

This study was performed in Sohag University Hospital, on 20 patients known to have HCV ,in addition to 20 healthy individuals (age- and sex- matched). Data was analyzed using Statistical package for social sciences (IBM-SPSS), version 24 IBMChicago, USA (May 2016).Quantitative data was represented as mean, standard deviation, median and range. Data was analyzed using student t-test to compare means of two groups and ANOVA for comparison of the means of three groups or more.

The mean age in group I is 53.2 years, SD 4.09 years and the range is (45-62years), the mean age in group II is 53.8 years, SD 5.5 years and the range is (46-66years). No significant difference was found in comparing diseased group with controls $(\mathrm{P}=0.77)$ as in figure $(1)$. 


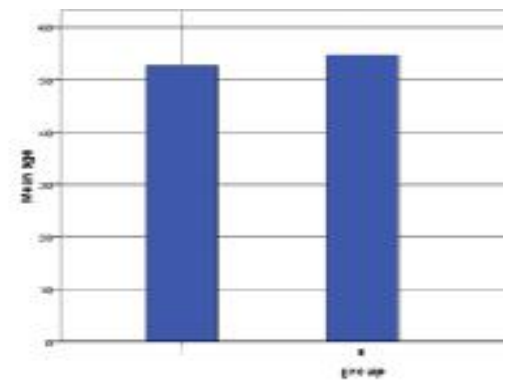

Figure (1):Comparison between the groups according to age.

All subjects in the control group had normal liver biochemistry but in CHC group was significantly higher (Table 1). As expected, serum AFP (ng/ml) was significantly higher in the CHC patients compared to the control group. Serum CLU (ng/ml) level showed a significant decrease in the $\mathrm{CHC}$ group compared to the control group ( Table 2).

Table (1):Liver function tests in the studied groups

\begin{tabular}{|r|c|c|c|}
\hline & $\begin{array}{c}\text { Group I } \\
\text { LC } \\
(\mathbf{n}=\mathbf{2 0})\end{array}$ & $\begin{array}{c}\text { Group II } \\
\text { Control } \\
(\mathbf{n = 2 0})\end{array}$ & P-value \\
& Mean \pm SD & Mean \pm SD & I versus II \\
\hline \multirow{2}{*}{ ALT (IU/ L) } & $73.9 \pm 27.4$ & $27.45 \pm 6.6$ & $0.02($ Sig) \\
& $45-123$ & $15-39$ & \\
\hline AST (IU/ L) & $81.65 \pm 24.67$ & $32.55 \pm 6.5$ & $<0.001(\mathbf{H S})$ \\
& $35-138$ & $18-41$ & \\
\hline TP (g/ dL) & $6.1 \pm 0.48$ & $7.29 \pm 0.35$ & $<0.001(\mathbf{H S})$ \\
\hline Albumin(g/ & $5.3-6.9$ & $6.6-7.9$ & \\
\hline dL) & $1.2 \pm 0.41$ & $4.55 \pm 0.46$ & $<0.001(\mathbf{H S})$ \\
\hline T.Bil (mg/ & $3.3 \pm 0.95$ & $3.9-5.2$ & \\
dL) & $1.6-4.9$ & $0.7 \pm 0.16$ & 0.04 (Sig) \\
\hline ALP (IU/ L) & $111.6 \pm 95.37$ & $0.5-1$ & \\
\hline & $35-361$ & $35-92$ & 0.03 (Sig) \\
\hline
\end{tabular}

Table (2):AFP and CLU in the studied groups

\begin{tabular}{|c|c|c|c|}
\hline & $\begin{array}{c}\text { Group I } \\
\text { LC } \\
(\mathbf{n}=\mathbf{2 0})\end{array}$ & $\begin{array}{c}\text { Group II } \\
\text { Control } \\
(\mathbf{n}=\mathbf{2 0})\end{array}$ & P value \\
& Mean \pm S.D & Mean \pm S.D & $\begin{array}{c}\text { I versus } \\
\text { II }\end{array}$ \\
\hline AFP & $\mathbf{2 1 . 4 9} \pm \mathbf{2 1 . 1 7}$ & $\mathbf{2 . 2 8} \pm \mathbf{1 . 3 3}$ & $<\mathbf{0 . 0 1}(\mathbf{H S})$ \\
$(\mathrm{ng} / \mathrm{mL})$ & $\mathbf{0 . 9 - 6 0 . 2}$ & $\mathbf{0 . 5 - 5 . 2}$ & \\
\hline CLU & $\mathbf{8 8 . 3} \pm \mathbf{3 0 . 7}$ & $\mathbf{1 1 0 . 7} \pm \mathbf{3 0 . 1}$ & $=\mathbf{0 .}$ \\
$(\mu \mathrm{g} / \mathrm{mL})$ & $\mathbf{3 2 - 1 5 0}$ & $\mathbf{6 0 - 1 6 4}$ & $\mathbf{0 3}(\mathbf{S i g})$ \\
\hline
\end{tabular}

\section{Discussion}

According to WHO 2012, every year, 3-4 million people are infected with the hepatitis $\mathrm{C}$ virus. About 150 million people are chronically infected and at risk of developing liver cirrhosis and/or liver cancer. More than 350000 people die from hepatitis C-related liver diseases every year.

AFP showed statistically significant elevation in group I LC patients as regard controls $(\mathrm{P}<0.01)$.The elevation of AFP occurs in hepatocyte regeneration, hepatocarcinogenesis, and embryonic carcinomas(Malaguarnera, 2010).

Serum CLU, Serum CLU showed a significant decrease in the LC group as regards controls. This may point to a possible protective role of CLU against liver cell fibrogenesis which ultimately ends in cirrhosis. Such an assumption was similarly postulated in renal 
fibrosis by Jung et al., 2012, who suggested that up regulation of clusterin during renal injury, in a mouse model, has a protective response against the development of renal fibrosis.

This is further sup-ported by the fact that clusterin exists as both an intracellular truncated form and an extracellular heterodimeric secreted glycoprotein, making clusterin the only known chaperone protein to be secreted(Chi et al., 2008).

CLU is a Golgi molecular chaperone involved in BAX- antiapoptotic processes, activation of the phosphatidylinositol 3-kinase/ protein kinase B pathway, promotion of angiogenesis, mediation of the nuclear factor kappa B (NF- $\mathrm{KB})$ pathway and modulation of extra-cellular signalregulated kinase (ERK) signaling. A number of biological processes, including programmed cell death (Down regulation allows for p53activation and cell death), lipid transport, membrane recycling and cell adhesion (Sansanwal et al.,2015, Lin et al.,2014). Serum clusterin was introduced as more specific and sensitive biomarker than AFP in distinction of HBV-cirrhosis with HCC base on HBV-cirrhosis (Wang et al.,2010). It also has been shown that clusterin may be a useful marker in the evaluation of prognosis of patients with alcoholic cirrhosis and severity of liver disease (Ehsani Ardakani et al.,2016). CLU involved in BAXantiapoptotic processes and it's down regulation allows p53 activation and cell death (Norouzinia et al.,2012).

\section{Conclusion}

CLU is decreased in the serum of patients with established CHC.

\section{References:}

1 . Abubakar, I. I., Tillmann, T., \& Banerjee, A. ,2015. Global, regional, and national age-sex specific all-cause and cause-specific mortality for 240 causes of death, 1990-2013: a systematic analysis for the Global Burden of Disease Study 2013. Lancet, 385(9963), 117-171.

2. Chi, K.N., Siu, L.L., Hirte, H., Hotte, S.J., Knox, J., Kollmansberger, C., Gleave, M., Guns, E., Powers, J., Walsh, W. and Tu, D., 2008. A phase I study of OGX-011, a 2'-methoxyethyl phosphorothioate antisense to clusterin, in combination with docetaxel in patients with advanced cancer. Clinical Cancer Research, 14(3), pp.833-839.

3. Debruyne, E.N., Vanderschaeghe, D., Van Vlierberghe, H., Vanhecke, A., Callewaert, N. and Delanghe, J.R., 2010. Diagnostic value of the hemopexin $\mathrm{N}$-glycan profile in hepatocellular carcinoma patients. Clinical chemistry, 56(5), pp.823-831.

4. Ehsani Ardakani, M. J., Safaei, A., Arefi Oskouie, A., Haghparast, H., Haghazali, M., Mohaghegh Shalmani, H., ... Zali, M. R. , 2016. Evaluation of liver cirrhosis and hepatocellular carcinoma using ProteinProtein Interaction Networks. Gastroenterology and Hepatology From Bed to Bench, 9(Suppl1), S14S22.

5. Gangadharan, B., Antrobus, R., Dwek, R. A., \& Zitzmann, N. ,2007. Novel serum biomarker candidates for liver fibrosis in hepatitis $\mathrm{C}$ patients. Clinical chemistry, 53(10), 1792-1799.

6. Jung, G.S., Kim, M.K., Jung, Y.A., Kim, H.S., Park, I.S., Min, B.H., Lee, K.U., Kim, J.G., Park, K.G. and Lee, I.K., 2012. Clusterin attenuates the development of renal fibrosis. Journal of the American Society of Nephrology, 23(1), pp.73-85.

7.Koltai, T., 2014. Clusterin: a key player in cancer chemoresistance and its inhibition. OncoTargets and therapy, 7 , p.447.

8 . Lin, C.C., Tsai, P., Sun, H.Y., Hsu, M.C., Lee, J.C., Wu, I.C., Tsao, C.W., Chang, T.T. and Young, K.C., 2014. Apolipoprotein J, a glucoseupregulated molecular chaperone, stabilizes core and NS5A to promote infectious hepatitis $\mathrm{C}$ virus virion 
production. Journal of hepatology, 61(5), pp.984-993.

-9. Malaguarnera, G., Giordano, M., Paladina, I., Berretta, M., Cappellani, A. and Malaguarnera, M., 2010. Serum markers of hepatocellular carcinoma. Digestive diseases and sciences, 55(10), pp.27442755.

10. Norouzinia, M., Asadzadeh, H., Shalmani, H.M., Al Dulaimi, D. and Zali, M.R., 2012. Clinical and histological indicators of proximal and distal gastric cancer in eight provinces of Iran. Asian Pacific Journal of Cancer Prevention, 13(11), pp.56775679
11. Sansanwal, P., Li, L. and Sarwal, M.M., 2015. Inhibition of intracellular clusterin attenuates cell death in nephropathic cystinosis. Journal of the American Society of Nephrology, 26(3), pp.612-625.

12 . Wang, Y., Liu, Y.H., Mai, S.J., He, L.J., Liao, Y.J., Deng, H.X., Guan, X.Y., Zeng, Y.X., Kung, H.F. and Xie, D., 2010. Evaluation of serum clusterin as a surveillance tool for human hepatocellular carcinoma with hepatitis B virus related cirrhosis. Journal of gastroenterology and hepatology, 25(6), pp.1123-1128. 
SOHAG MEDICALJOURNAL Serum Clusterin In Patients With Chronic HCV infection Related Cirrhosis 